\title{
Erratum to: Basal cell cystadenoma of the lacrimal gland: diagnostic pitfalls of a basaloid pattern in lacrimal tumours
}

\author{
Jonathan E. Silbert • Puneet S. Braich • \\ Raghunath P. Misra
}

Published online: 23 June 2015

(C) Springer Science+Business Media Dordrecht 2015

\section{Erratum to: Int Ophthalmol (2011) 31:43-46 DOI 10.1007/s10792-010-9392-x}

The name of one of the co-authors is incorrect in the original publication.

The name Puneet Braich should read as Puneet S. Braich and it has been corrected in this erratum.

The online version of the original article can be found under doi:10.1007/s10792-010-9392-x.

J. E. Silbert $(\square)$

The Eye Care Group, 40-60 Temple Street, Suite 5-B, New Haven, CT 06510-2715, USA

e-mail: jonsilbert@theeyecaregroup.com

\section{J. E. Silbert}

Department of Ophthalmology, Yale University School of Medicine, Yale Eye Center Suite 3B, 40 Temple St, New Haven, CT 06510, USA

\section{P. S. Braich}

Ross University School of Medicine, Dominica,

West Indies

P. S. Braich

Clinical Campus: 7000 Southwest 62nd Avenue,

South Miami, FL 33143-4716, USA
R. P. Misra

Department of Ophthalmology, Louisiana State

University Health Sciences Center, 1501 Kings Highway, P.O. Box 33932, Shreveport, LA 71130, USA 